\title{
Two new species of graptolite from the Telychian (upper Llandovery, Silurian), of Kallholn, Dalarna, Sweden
}

David K. Loydell and Natalia Walasek

School of the Environment, Geography and Geosciences, University of Portsmouth, United Kingdom

CONTACT David K. Loydell david.loydell@port.ac.uk

\section{ABSTRACT}

Two new species of graptolite are described from the lower part of the Spirograptus turriculatus Biozone (lower Telychian) of Kallholn Quarry, Dalrana, Sweden. Pristiograptus paradoxus sp. nov. is ventrally curved and is more similar to uppermost Wenlock-Ludlow Bohemograptus species than to other Llandovery Pristiograptus species. Torquigraptus loveridgei sp. nov. is stratigraphically intermediate between the well-known species, T. planus and T. proteus.

\section{KEYWORDS}

Graptolite; Silurian; Llandovery; Sweden

\section{Introduction}

Numerous graptolites were collected to enable Walasek et al.'s (2018) revision of the graptolite biostratigraphy of the Llandovery of Kallholn Quarry, Dalarna, Sweden. Amongst these, two new species were encountered, both of which are from the lower part of the Spirograptus turriculatus Biozone (lower Telychian) of the northern quarry entrance road section (Walasek et al. 2018, fig. 1). Both are morphologically atypical for the lower Telychian, having a greater resemblance to taxa from higher in the Silurian than to contemporary species. The two new species are described and discussed below. They co-occur in two samples, in which they are accompanied by typical lower turriculatus Biozone species: Spirograptus turriculatus (Barrande), abundant Streptograptus johnsonae Loydell, Monograptus marri Perner, Pristiograptus bjerringus Bjerreskov, etc. All material is preserved as diagenetically flattened original periderm with no tectonic distortion; the periderm has flaked off to a variable extent, leaving all specimens as a combination of original periderm and low relief external mould. Specimens are housed in the Museum of Evolution, Uppsala University, Sweden. Section measurements below are upwards from the base of the Kallholn Formation. Thecal spacing measurements are given as two thecae repeat distances (2TRD; Howe 1983).

\section{Systematic Palaeontology}

Pristiograptus paradoxus sp. nov.

Figures $1 C-E, 2 A-B$

Derivation of name. - From the Latin for strange, contrary to expectation. 
Material. - 9 specimens, including 4 proximal ends, from the following samples: $9.56-9.61 \mathrm{~m} \mathrm{(4}$ specimens), 9.76-9.81 m (1 specimen, the holotype) and $10.54 \mathrm{~m}$ (1 specimen); 3 ex situ specimens were also collected.

Holotype. - PMU 35064, Fig. 1C, a proximal end bearing ten thecae, from 9.76-9.81 m above the base of the Kallholn Formation, lower Spirograptus turriculatus Biozone (lower Telychian), northern quarry entrance road section, Kallholn Quarry, Dalarna, Sweden.

Diagnosis. - Pristiograptus with ventrally curved rhabdosome, the curvature accentuated mesially. Short sicula, c. $1.1 \mathrm{~mm}$ long, apex reaches just below the aperture of th1. Dorso-ventral width increases gradually from $0.4 \mathrm{~mm}$ proximally to a distal maximum of $1 \mathrm{~mm}$. Thecae are widely spaced, simple tubes, inclined at $25-30^{\circ}$ to the rhabdosome axis, with 2 TRDs of $2.0-2.5 \mathrm{~mm}$ proximally and 1.9-2.6 mm mesially and distally.

Description. - The longest (incomplete) specimen is $34 \mathrm{~mm}$ long. The rhabdosome is straight or very gently ventrally curved initially, with more pronounced ventral curvature commencing at around th4-th6, with this curvature being maintained mesially and reducing in intensity towards the distalmost part of the longest specimen collected (Fig. 2A). The sicula is 1.05-1.1 mm long, with an apertural width of $0.2 \mathrm{~mm}$. The aperture is concave; the virgella is not completely preserved on any specimen. The sicular apex attains a level just below the aperture of th1. Thecae are simple tubes inclined at $25-30^{\circ}$ to the rhabdosome axis. Thecal apertures are straight or in a few thecae very slightly concave and generally are perpendicular to the thecal axis; the exceptions are mostly proximal thecae in which the aperture is at up to $80^{\circ}$ to the thecal axis. Thecal overlap increases from one-fifth-one-sixth of the thecal length proximally, to approximately one-half distally. Dorsoventral width measurements are $0.4-0.45 \mathrm{~mm}$ (th1), 0.4-0.55 mm (th3), 0.45-0.6 mm (th5), 0.7$0.75 \mathrm{~mm}$ (th10) and 0.8-1.0 mm distally. 2TRD measurements are $1.9-2.25 \mathrm{~mm}$ (th2), 2.2-2.4 mm (th5) and 1.9-2.6 mm mesially and distally.

Remarks. - Pristiograptus paradoxus sp. nov. is highly distinctive, its ventral curvature being most reminiscent of later Silurian species assigned to Bohemograptus, in particular B. praecox Štorch et al., 2016 from the uppermost Wenlock and lower Ludlow. This has a similar dorso-ventral width to $P$. paradoxus sp. nov. both proximally and distally, but differs in having a wider sicular aperture (0.3$0.4 \mathrm{~mm}$ ) and greater thecal overlap (one-third) proximally. Also very similar is Bohemograptus garratti Rickards et al., 1993 from the middle Ludlow. The type material of this is tectonically deformed; undeformed, well-preserved specimens from Kyrghizstan were described by Koren' and Sujarkova (2004). Bohemograptus garratti also has similar proximal and distal dorso-ventral width to Pristiograptus paradoxus, although this increases more rapidly over the first few thecae (at th5 it is 0.65-0.7 $\mathrm{mm}$ ). Thecae are, however, inclined at a lower angle to the rhabdosome axis, especially proximally $\left(10^{\circ}\right.$ proximally, $20-25^{\circ}$ distally) and it has more widely spaced thecae (2TRD is $2.5-3.0$ $\mathrm{mm}$ ). Finally, Bohemograptus singularis Koren' and Sujarkova, 2004, also from the middle Ludlow, again is similar in terms of dorso-ventral width (and in its rate of increase proximally) to Pristiograptus paradoxus but thecal overlap is less both mesially and distally. Of Llandovery species, Pristiograptus variabilis (Perner, 1897) has similar dorso-ventral width measurements, but has a straight rhabdosome and more closely spaced thecae proximally (see fig. 22AA in Loydell et al., 2015). Gentle ventral curvature is recorded in a few Telychian Pristiograptus species, but these are very different in terms of overall appearance. For example, in Pristiograptus huttae Loydell, 1993 the thecae are much more closely spaced proximally and rhabdosome dorso-ventral width immediately above thecal apertures is much greater; in Pristiograptus macrodon Štorch, 1992 the first two thecae are very closely spaced and the rhabdosome is much narrower immediately above the very wide thecal apertures. 
Torquigraptus loveridgei sp. nov.

Figures $1 \mathrm{~A}-\mathrm{B}$

Derivation of name. - After Bob Loveridge who assisted the authors with fieldwork at Kallholn and the senior author on many other occasions over many years.

Material. - 5 specimens, including 1 proximal end (the holotype) from the following samples: 9.56$9.61 \mathrm{~m}$ ( 2 specimens, including the holotype) and 9.76-9.81 m (3 specimens).

Holotype. - PMU 35062, Fig. 1A, a proximal end bearing 19 thecae, from 9.56-9.61 m above the base of the Kallholn Formation, lower Spirograptus turriculatus Biozone (lower Telychian), northern quarry entrance road section, Kallholn Quarry, Dalarna, Sweden.

Diagnosis. - Rhabdosome dorsally curved proximally and mesially, becoming almost straight distally. Thecae are axially elongated throughout, but especially proximally, where prothecal bases are narrow. Dorso-ventral width increases steadily from $0.3 \mathrm{~mm}$ at th1 to distal values of $1.3-1.5 \mathrm{~mm}$. 2TRD decreases from $3.0 \mathrm{~mm}$ proximally to $2.4-2.6 \mathrm{~mm}$ mesially and distally.

Description. - The longest (incomplete) specimen is approximately $28 \mathrm{~mm}$ long. The rhabdosome is dorsally curved proximally and mesially, with this curvature accentuated between th4 and th10; distally the rhabdosome is straight. Only one specimen (the holotype) has the proximal end preserved. In this the sicula is $1.4 \mathrm{~mm}$ long with an apertural width of $0.15 \mathrm{~mm}$. The sicular apex reaches about two-thirds up th1. Th1 emerges $0.25 \mathrm{~mm}$ above the sicular aperture which is furnished with a short $(0.15 \mathrm{~mm}$ long, but possibly incomplete), narrow virgella. Thecae lack overlap and are axially elongated throughout the rhabdosome. The base of the protheca is very narrow in proximal thecae, about $15 \%$ of the maximum dorso-ventral width of the theca; this increases to $40 \%$ distally. In better-preserved thecae the apertures, which are slightly expanded laterally, can clearly be seen to be twisted towards the reverse side of the rhabdosome. In the proximal end dorso-ventral width increases from $0.3 \mathrm{~mm}$ at th1 and th2, to $0.4 \mathrm{~mm}$ at th3, $0.55 \mathrm{~mm}$ at th5, $1.05 \mathrm{~mm}$ at th $10,1.2 \mathrm{~mm}$ at th 15 and $1.5 \mathrm{~mm}$ at th19. Thecae are widely spaced, especially proximally: 2 TRD is $3.0 \mathrm{~mm}$ at th2, th3 and th5 and is 2.4$2.45 \mathrm{~mm}$ at th10, th15 and th18. The highest distal value recorded is $2.6 \mathrm{~mm}$.

Remarks. - Torquigraptus loveridgei sp. nov. differs from the other dorsally curved Torquigraptus species known from the lowermost Spirograptus turriculatus Biozone, T. planus (Barrande, 1850) and $T$. cavei Loydell, 1993, in being more robust proximally and in having more widely spaced thecae that are less triangular and more axially elongated distally. Several Torquigraptus species are recorded from higher in the Telychian and $T$. loveridgei is more similar to some of these, e.g. $T$. tullbergi (Bouček, 1931) and T. spiraloides (Přibyl, 1945). However, the thecae are more widely spaced and more axially elongated distally in $T$. loveridgei. Stratigraphically in the Kallholn quarry section $T$. loveridgei is present in the interval between the last appearance of $T$. planus (8.29-8.39 $\mathrm{m}$ ) and the first of the loosely helically coiled T. proteus (Barrande, 1850) at $10.54 \mathrm{~m}$. 


\section{Acknowledgments}

We thank Melissa Howard for donation of one of the ex situ specimens of Pristiograptus paradoxus sp. nov. and Jan Ove Ebbestad for providing very useful advice regarding fieldwork in the Siljan region.

\section{Disclosure statement}

No potential conflict of interest was reported by the authors.

\section{ORCID}

David K. Loydell http://orcid.org/0000-0003-3967-0047

\section{References}

Barrande, J., 1850. Graptolites de Bohême. Prague.

Bouček, B., 1931. Předběžná zpráva o některých nových druzích graptolitů v českém Gothlandienu. Věstník Státního Geologického Ústavu Republiky Československé 7(3), 293-313.

Howe, M.P.A., 1983. Measurement of thecal spacing in graptolites. Geological Magazine 120, 635638.

Koren', T.N. \& Sujarkova, A.A., 2004. The Ludlow (Late Silurian) neocucullograptid fauna from the southern Tien Shan, Kyrghizstan. Alcheringa 28, 333-387.

Loydell, D.K., 1993. Upper Aeronian and lower Telychian (Lladovery) graptolites from western midWales. Part 2. Monograph of the Palaeontographical Society 147(592), 56-180, pls 2-5.

Loydell, D.K., Frýda, J., \& Gutiérrez-Marco, J.C., 2015. The Aeronian/Telychian (Llandovery, Silurian) boundary, with particular reference to sections around the El Pintado reservoir, Seville Province, Spain. Bulletin of Geosciences 90, 743-794.

Perner, J., 1897. Études sur les Graptolites de Bôheme. Ilième Partie. Monographie des Graptolites de L'Étage E. Section a. Prague.

Přibyl, A., 1945. O středoevropských monograptech z rodu Spirograptus Gürich. Rozpravy České Akademie Věd Umění, Třidy 2 54(19), 1-46.

Rickards, R.B., Davidson, G.J. \& Banks, M.R., 1993. Silurian (Ludlow) graptolites from Golden Ridge, NE Tasmania. Memoir of the Association of Australasian Palaeontologists 15, 125-135.

Štorch, P., 1992. Some new and little known graptolites from the Lower Silurian of Bohemia (Prague Basin, Barrandian Area). Časopis pro Mineralogii a Geologii 37, 193-201, pls 1-2.

Štorch, P., Manda, Š., Slavík, L. \& Tasáryová, Z., 2016. Wenlock-Ludlow boundary interval revisited: new insights from the offshore facies of the Prague Synform, Czech Republic. Canadian Journal of Earth Sciences 53, 666-673. 
Walasek, N., Loydell, D.K., Frýda, J., Männik, P. \& Loveridge, R. F., 2018. Integrated graptoliteconodont biostratigraphy and organic carbon chemostratigraphy of the Llandovery of Kallholn quarry, Dalarna, Sweden. Palaeogeography, Palaeoclimatology, Palaeoecology 508, 1-16.

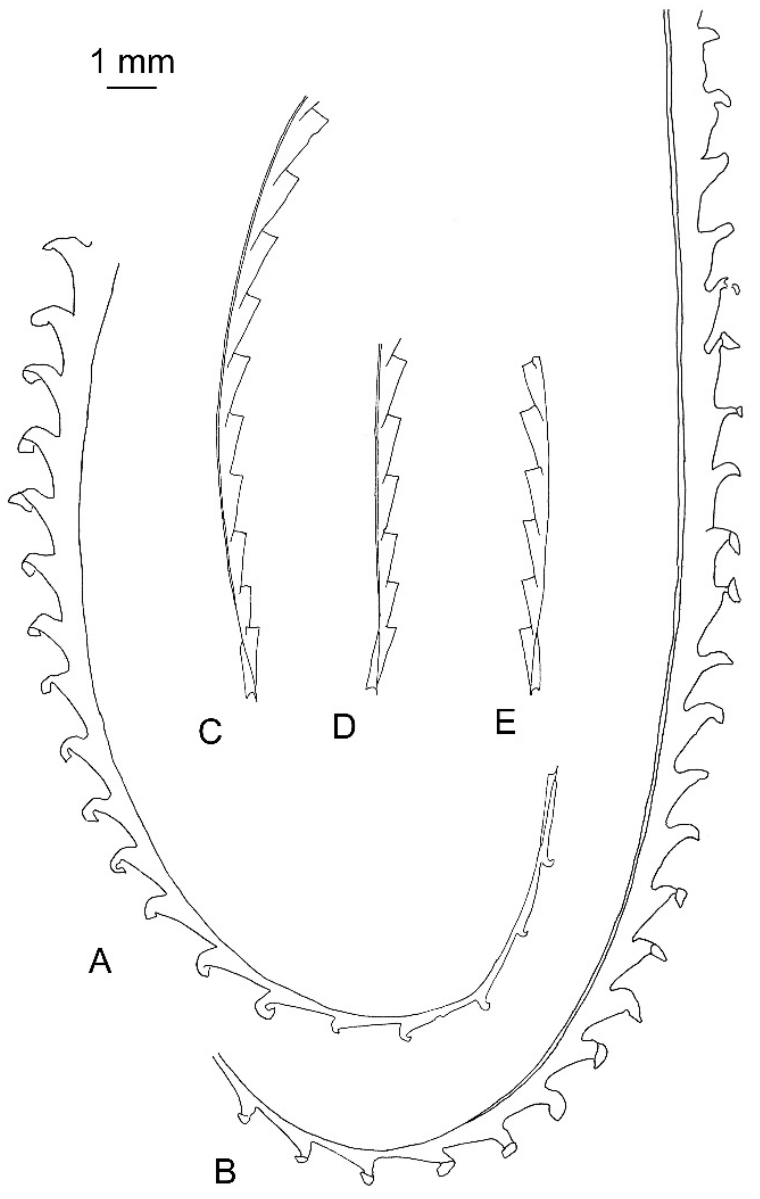

Fig. 1. New species from the lower Spirograptus turriculatus Biozone of Kallholn Quarry. A, B. Torquigraptus loveridgei sp. nov. A. Holotype, PMU 35062, from 9.56-9.61 m. B. PMU 35063, specimen lacking proximal end, but with long straight distal portion, from 9.76-9.81 m. C-E. Pristiograptus paradoxus sp. nov. C. Holotype, PMU 35064, from 9.56-9.61 m. D. Proximal end, PMU 35065, from 9.56-9.61 m. E. Proximal end, PMU 35066, ex situ specimen. 


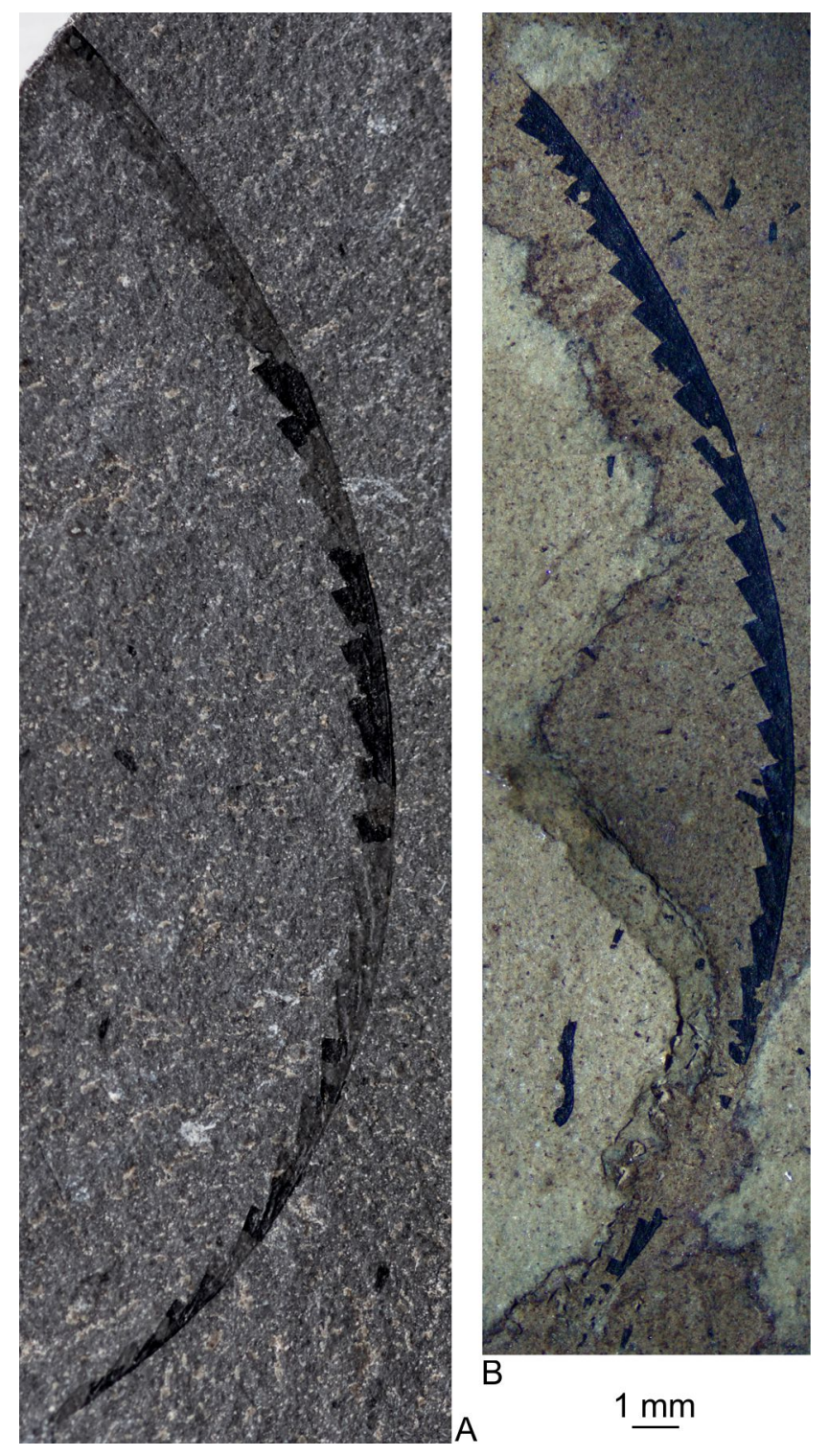

Fig. 2. Pristiograptus paradoxus sp. nov., specimens lacking a sicula but showing the overall rhabdosome shape. A. PMU 35067, ex situ specimen. B. PMU 35068, from 9.76-9.81 m. 